\title{
PTEN in Hereditary and Sporadic Cancer
}

\author{
Joanne Ngeow ${ }^{1,2,3}$ and Charis Eng $3,4,5,6$ \\ ${ }^{1}$ Lee Kong Chian School of Medicine, Nanyang Technological University, Singapore 639798 \\ ${ }^{2}$ Cancer Genetics Service, Division of Medical Oncology, National Cancer Centre, Singapore 169610 \\ ${ }^{3}$ Genomic Medicine Institute, Lerner Research Institute, Cleveland Clinic, Cleveland, Ohio 44195, USA \\ ${ }^{4}$ Taussig Cancer Institute, Cleveland Clinic, Cleveland, Ohio 44195, USA \\ ${ }^{5}$ Department of Genetics and Genome Sciences, Case Western Reserve University School of Medicine, \\ Cleveland, Ohio 44106, USA \\ ${ }^{6}$ Germline High Risk Cancer Focus Group, CASE Comprehensive Cancer Center, Case Western Reserve \\ University, Cleveland, Ohio 44106, USA \\ Correspondence: engc@ccf.org
}

Germline pathogenic phosphatase and tensin homolog (PTEN) mutations cause PTEN hamartoma tumor syndrome (PHTS), characterized by various benign and malignant tumors of the thyroid, breast, endometrium, and other organs. Patients with PHTS may present with other clinical features such as macrocephaly, intestinal polyposis, cognitive changes, and pathognomonic skin changes. Clinically, deregulation of PTEN function is implicated in other human diseases in addition to many types of human cancer. PTEN is an important phosphatase that counteracts one of the most critical cancer pathways: the phosphatidylinositol 3-kinase (PI3K)/AKT signaling pathways. Although PTEN can dephosphorylate lipids and proteins, it also has functions independent of phosphatase activity in normal and pathological states. It is positively and negatively regulated at the transcriptional level as well as posttranslationally by phosphorylation, ubiquitylation, oxidation, and acetylation. Although most of its tumor-suppressor activity is likely to be caused by lipid dephosphorylation at the plasma membrane, PTEN also resides in the cytoplasm and nucleus, and its subcellular distribution is under strict control. In this review, we highlight our current knowledge of PTEN function and recent discoveries in understanding PTEN function regulation and how this can be exploited therapeutically for cancer treatment.

$T_{t}^{\text {h }}$ he tumor-suppressor gene phosphatase and tensin homolog (PTEN) (OMIM 601728) was originally recognized as mutated somatically in multiple sporadic cancers (Li et al. 1997; Steck et al. 1997), as well as mutated in the germline of patients with Cowden syndrome (CS; OMIM 158350), a hereditary overgrowth and cancer predisposition disorder (Nelen et al. 1996;
Liaw et al. 1997). PTEN is a dual specificity phosphatase that canonically negatively regulates the phosphatidylinositol 3-kinase (PI3K) signaling cascade. Through its lipid phosphatase activity, PTEN dephosphorylates phosphatidylinositol 3,4,5-trisphosphate $\left(\mathrm{PIP}_{3}\right)$ to phosphatidylinositol 4,5-bisphosphate $\left(\mathrm{PIP}_{2}\right)$, thereby dampening downstream protein kinase $\mathrm{B}$

Editors: Charis Eng, Joanne Ngeow, and Vuk Stambolic

Additional Perspectives on The PTEN Family available at www.perspectivesinmedicine.org

Copyright (C) 2020 Cold Spring Harbor Laboratory Press; all rights reserved; doi: 10.1101/cshperspect.a036087

Cite this article as Cold Spring Harb Perspect Med 2020;10:a036087 
$(\mathrm{PKB} / \mathrm{AKT})$ signaling (Maehama and Dixon 1998; Stambolic et al. 1998). Left unchecked, such as through PTEN mutation or inactivation, elevated $\mathrm{PIP}_{3}$ levels cause constitutive activation of AKT and downstream cascades such as mammalian target of rapamycin (mTOR) signaling (Inoki et al. 2002). This ultimately leads to cell survival, growth, proliferation, and decreased apoptosis (Furnari et al. 1997; Di Cristofano et al. 1998; Weng et al. 1999). Although originally believed to be an exclusively cytoplasmic phosphatase, PTEN is now known to also function within the nucleus to regulate the cell cycle, double-strand break repair, genomic stability, and chromatin remodeling (Wu et al. 1998; Weng et al. 2001a,b; Baker 2007; Shen et al. 2007; Chen et al. 2014). Therefore, PTEN is characterized by various phosphatase-dependent and -independent cellular functions (Fig. 1; Lee et al. 2018; for additional information on PTEN signaling, see Shen 2019; Lee and Trotman 2019; Yang and Yin 2019.

Germline PTEN mutations have been identified in patients with different clinical syndromes, and the mutation-positive subset is termed PTEN hamartoma tumor syndrome (PHTS) (Marsh et al. 1999; Eng 2016; for review, see Yehia et al. 2019). Besides PTEN mutationpositive CS, PHTS also encompasses individuals with Bannayan-Riley-Ruvalcaba syndrome (BRRS) and Proteus syndrome (PS) and Proteus-like syndrome who have germline PTEN mutations (Zhou et al. 2001; Smith et al. 2002; Kirk et al. 2004; Loffeld et al. 2006; Eng 2016). BRRS (OMIM 153480) is a rare congenital disorder classically characterized by macrocephaly in combination with intestinal hamartomatous polyposis, vascular malformations, lipomas, hemangiomas, and genital freckling (Ruvalcaba et al. 1980; Gorlin et al. 1992). PS (OMIM $176920)$ is a rare, complex, and highly variable disorder characterized by progressive, postnatal overgrowth of multiple tissues derived from different cell lineages (Cohen and Hayden 1979). Relatedly, germline and somatic mosaic mutations in other genes encoding components of the $\mathrm{PI} 3 \mathrm{~K} / \mathrm{AKT} / \mathrm{mTOR}$ signaling pathway downstream of PTEN predispose patients to partially overlapping sets of clinical manifestations rem- iniscent of PHTS, referred to as PTEN-opathies (Yehia et al. 2019).

\section{PTEN DYSFUNCTION AND HERITABLE CANCER}

The identification of germline PTEN mutations allowed for the comprehensive elucidation of component cancers and associated lifetime risks in individuals with PHTS (Tan et al. 2012). Three independent studies revealed elevated risks for breast, thyroid, endometrial, kidney, and colon cancers and melanoma in PHTS (Table 1; Tan et al. 2012; Bubien et al. 2013; Nieuwenhuis et al. 2014). Similar to other hereditary cancer syndromes, the risk for bilateral and multifocal cancer is elevated (Eng 2016). Relatedly, individuals with PHTS have a sevenfold increased risk of developing second malignant primary neoplasms (Ngeow et al. 2014). Collectively, these cancer risk-assessment studies inform clinical surveillance recommendations and medical management of individuals with germline PTEN mutations (Tan et al. 2012), with the aim of detecting malignancies at the earliest, most manageable stages (Table 2).

PTEN comprises nine exons encoding a 403 amino acid protein (Fig. 2A; Li et al. 1997; Li and Sun 1997). Broadly, PTEN mutations could impact the abundance of PTEN protein resulting in haploinsufficiency, result in reduced or lost phosphatase activity, act in a dominant-negative manner, and/or result in aberrant localization and function (Lee et al. 2018). The germline mutation spectrum in PHTS is broad, with mutations affecting all nine exons of PTEN (Fig. 2B; Tan et al. 2011, 2012; Mester and Eng 2013; Ngeow et al. 2014). Approximately two-thirds of germline PTEN mutations occur in exons 5, 7 , and 8 , encoding the phosphatase domain (Tan et al. 2011). Interestingly, up to $40 \%$ of all germline PTEN mutations are located in exon 5, encoding the core catalytic motif, although this exon represents only $20 \%$ of the coding sequence (Waite and Eng 2002; Eng 2003; Tan et al. 2011). Relatedly, two distinct Alu elements have been reported in two unrelated CS patients with identical breakpoints within exon 5, suggesting that this exon is a possible retrotranspo- 


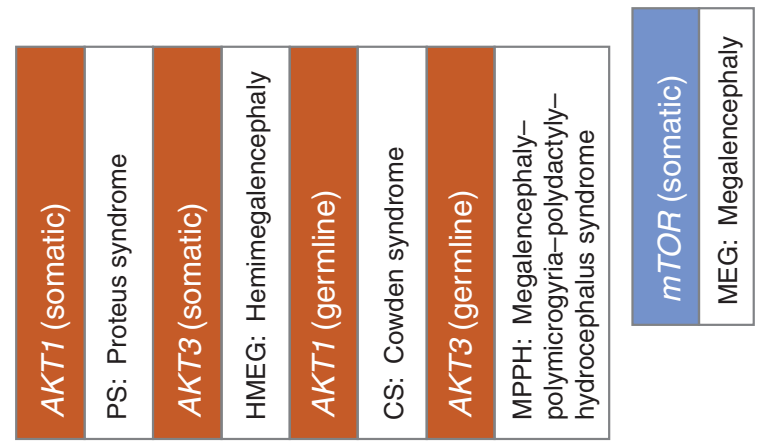

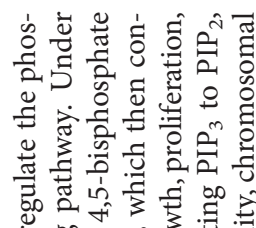

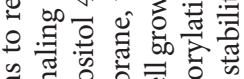

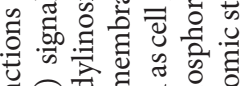

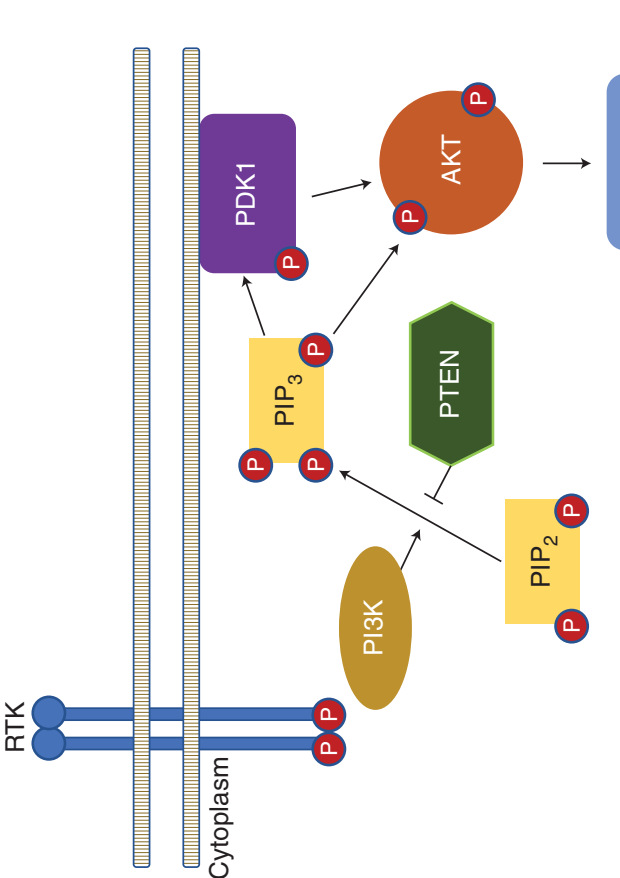

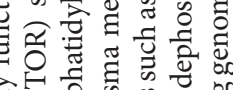

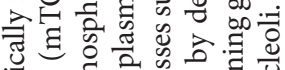

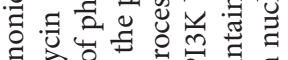
ฮี

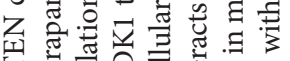

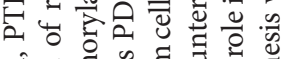
हี

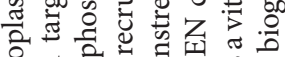

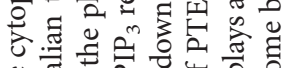

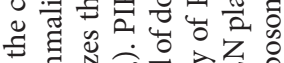
घ

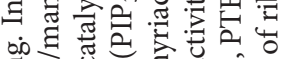

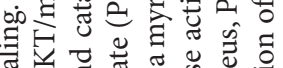

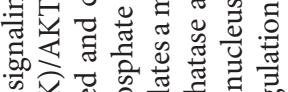

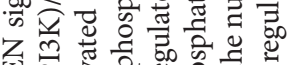

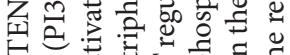

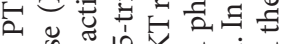

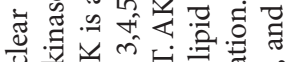

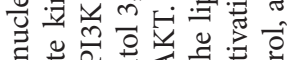

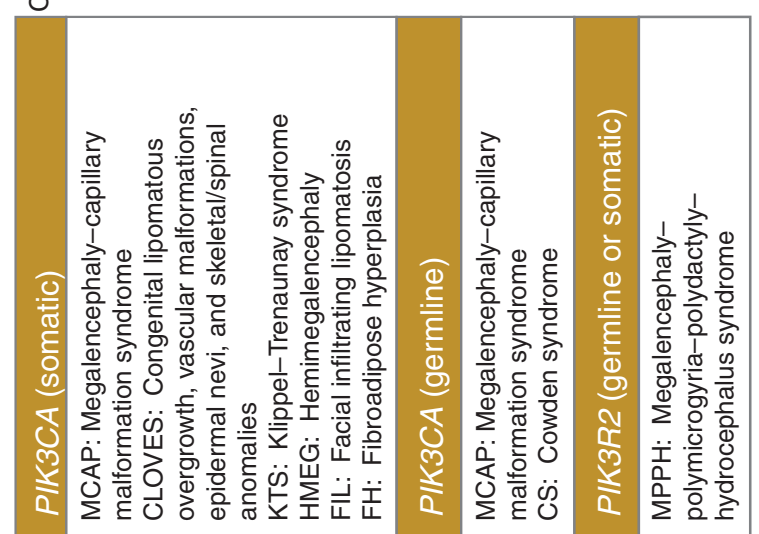

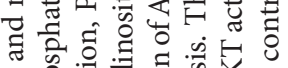

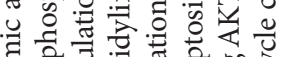
表

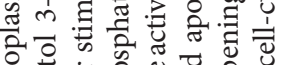

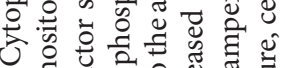

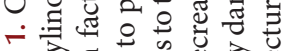

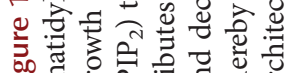

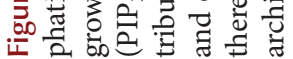


J. Ngeow and C. Eng

Table 1. Component cancer risks in PHTS patients

\begin{tabular}{lcc}
\hline Cancer & Population risk (SEER) $(\%)$ & Lifetime risk in PHTS $(\%)$ \\
\hline Breast (female) & 12 & $67-85$ \\
Thyroid & 1 & $6-38$ \\
Endometrial & 2.6 & $21-28$ \\
Renal cell & 1.6 & $2-34$ \\
Colon & 5 & $9-17$ \\
Melanoma & 2 & $2-6$ \\
\hline
\end{tabular}

Table created from data in Tan et al. (2012), Bubien et al. (2013), and Nieuwenhuis et al. (2014). Lifetime risks calculated to age 70 by Tan et al. (2012) and Bubien et al. (2013), and to age 60 by Nieuwenhuis et al. (2014). Cancer risk percent ranges reflect lowest and highest frequencies reported in all three studies.

(SEER) surveillance, epidemiology, and end results, (PHTS) PTEN hamartoma tumor syndrome.

sition hotspot (Crivelli et al. 2017). Mutations within the core catalytic motif typically abrogate pan-phosphatase (lipid and protein) activity such as mutations affecting p.Cys124, but, rarely, mutations such as p.Gly129Glu result in abrogation of lipid phosphatase activity only (Liaw et al. 1997; Myers et al. 1998; Davidson et al. 2010).

PTEN protein domains have distinct functions (Fig. 2A). For example, the aminoterminal phosphatase domain contains two ATP-binding motifs, critical for regulating PTEN exit from the nucleus (Lobo et al. 2008). ATP-binding motif mutants (e.g., p.K62R, p.Y65C, p.K125E) do not bind ATP efficiently, resulting in nuclear PTEN mislocalization. This subsequently leads to increased cellular proliferation, reduced/abrogated apoptosis, and increased anchorage-independent growth, leading to carcinogenesis (Lobo et al. 2009; He et al. 2011a). Mechanistically, nuclear mislocalization of PTEN results in both overexpression of p-AKT due to compromised cytoplasmic lipid phosphatase activity and loss of control over cyclin D1 levels, an important regulator of $G_{1}$ to S-phase cell-cycle transition downstream of PTEN (Weng et al. 2001a; He et al. 2011a). Additionally, PTEN ATP-binding mutations result in decreased nuclear $\mathrm{p} 53$ protein levels and transcriptional activity, as well as accumulation of oxidative DNA damage due to elevated reactive oxygen species (ROS) production. Indeed, mutant cells exhibit decreased transcript levels of TP53INP1, a major mediator of p53-mediated antioxidant function (Cano et al. 2009). Finally, compared to wild-type PTEN, subsets of ATP- binding mutants have reduced PTEN protein stability, both in vitro and in vivo (He et al. 2011a).

Other mutations affecting amino acids critical for PTEN posttranslational regulation also offer important insights. For example, catalytically active mutant PTEN p.Lys289Glu is characterized by a nuclear import defect due to loss of monoubiquitination at p.Lys289 (Trotman et al. 2007). Hence, the p.Lys 289 Glu protein is reminiscent of a cytoplasmic-predominant phenotype and compromised nuclear PTEN tumorsuppressive function (Fig. 1). Nuclear PTEN is thought to be protected from polyubiquitination and subsequent proteasome-mediated degradation in the cytoplasm and is able to dampen AKT signaling and induce p53-independent apoptosis (Trotman et al. 2007). In support of these observations, nuclear exclusion of PTEN has been associated with more aggressive advanced-stage sporadic cancers (Gimm et al. 2000; Zhou et al. 2000, 2002; Tachibana et al. 2002; Whiteman et al. 2002).

Aside from intragenic mutations, $\sim 10 \%$ of CS patients harbor germline PTEN promoter mutations (Zhou et al. 2003b). Pathogenic promoter mutations result in decreased PTEN transcription and translation, the latter due to altered mRNA secondary structure (Zhou et al. 2003b; Teresi et al. 2007). More recently, some unsuspected PTEN intronic variants were shown to result in pathogenic exon skipping, alternative splicing, or the use of cryptic splice sites (Chen et al. 2017b). These splicing changes correlate with significantly lower PTEN protein 
PTEN in Hereditary and Sporadic Cancer

Table 2. Screening and management recommendations for PHTS

\begin{tabular}{|c|c|c|c|}
\hline & Screening/surgical guidelines ${ }^{\mathrm{a}}$ & Age to start & Frequency \\
\hline \multirow[t]{4}{*}{ Breast } & $\begin{array}{l}\text { Breast awareness and self-exam: } \\
\text { report changes to health care } \\
\text { provider }\end{array}$ & 18 & Consistent \\
\hline & Clinical breast exam & $25^{\mathrm{b}}$ & Every 6-12 months \\
\hline & $\begin{array}{l}\text { Mammogram with consideration } \\
\text { of tomosynthesis and breast } \\
\text { MRI with contrast }\end{array}$ & $30-35^{\mathrm{b}}$ & Every 12 months \\
\hline & Discuss mastectomy & Personalized & As needed \\
\hline Thyroid & Thyroid ultrasound & $\begin{array}{l}\text { Time of PHTS diagnosis, } \\
\text { including childhood }\end{array}$ & Every 12 months \\
\hline Kidney & Consider renal ultrasound & 40 & Every $1-2$ years \\
\hline \multirow[t]{4}{*}{ Endometrium } & $\begin{array}{l}\text { Encourage patient education and } \\
\text { prompt response to symptoms } \\
\text { (e.g., abnormal bleeding) }\end{array}$ & Not applicable & Not applicable \\
\hline & $\begin{array}{l}\text { Consider screening via } \\
\text { endometrial biopsy }\end{array}$ & Not applicable & Every $1-2$ years \\
\hline & $\begin{array}{l}\text { Transvaginal ultrasound in } \\
\text { postmenopausal women at the } \\
\text { clinician's discretion }\end{array}$ & Not applicable & As needed \\
\hline & $\begin{array}{l}\text { Discuss hysterectomy with } \\
\text { completion of childbearing }\end{array}$ & Personalized & As needed \\
\hline Colon & Colonoscopy & $35^{\mathrm{b}}$ unless symptomatic & $\begin{array}{l}\text { Every } 5 \text { years or more frequently } \\
\text { depending on whether patient is } \\
\text { symptomatic or polyps are found }\end{array}$ \\
\hline Dermatologic & Dermatologic exam & Personalized & Clinician's recommendation \\
\hline \multirow[t]{2}{*}{ Developmental } & $\begin{array}{l}\text { Consider psychomotor } \\
\text { assessment in children }\end{array}$ & Time of PHTS diagnosis & Clinician's recommendation \\
\hline & Brain MRI if symptomatic & Time of PHTS diagnosis & Clinician's recommendation \\
\hline
\end{tabular}

Table adapted, with permission, from the NCCN Clinical Practice Guidelines in Oncology (NCCN Guidelines) for Genetic/ Familial High-Risk Assessment: Breast and Ovarian V.1.2019. @ 2018 National Comprehensive Cancer Network. All rights reserved. The NCCN Guidelines and illustrations herein may not be reproduced in any form for any purpose without the express written permission of NCCN. To view the most recent and complete version of the NCCN Guidelines, go online to NCCN.org. The NCCN Guidelines are a work in progress that may be refined as often as new significant data becomes available. NCCN makes no warranties of any kind whatsoever regarding their content, use or application and disclaims any responsibility for their application or use in any way.

(PHTS) PTEN hamartoma tumor syndrome, (MRI) magnetic resonance imaging.

${ }^{\mathrm{a}}$ Annual Comprehensive physical exam starting at age 18 or 5 years before the youngest age of diagnosis of a component cancer in the family (whichever comes first), with particular attention to thyroid exam. Encourage patient education regarding the signs and symptoms of cancer.

${ }^{\mathrm{b} C a n c e r ~ s c r e e n i n g ~ s h o u l d ~ b e g i n ~ 5-10 ~ y e a r s ~ b e f o r e ~ t h e ~ e a r l i e s t ~ k n o w n ~ c o m p o n e n t ~ c a n c e r ~ i n ~ t h e ~ f a m i l y ~ o r ~ a c c o r d i n g ~ t o ~ t h e ~}$ ages listed in the above table, whichever comes first.

levels and elevated p-AKT in patients with splicing changes compared to those without aberrant splicing. Finally, large PTEN deletions occur in $\sim 3 \%-10 \%$ of PHTS patients and can be found over the entire coding sequence (Zhou et al. 2003b; Tan et al. 2011; Mester and Eng 2013).

\section{GENOTYPE-PHENOTYPE CORRELATIONS AND MODIFIERS OF CANCER RISKS IN PHTS}

As with other inherited cancer syndromes, although it is possible to risk-assess increased organ-specific cancer probabilities, it is still impos- 
J. Ngeow and C. Eng

A

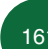

61 Missense

244

Truncating splicing

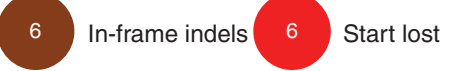

14 Promoter
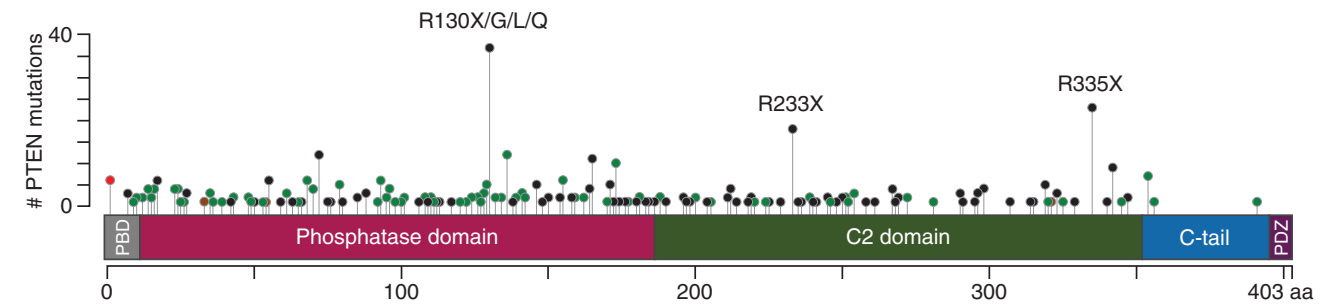

B

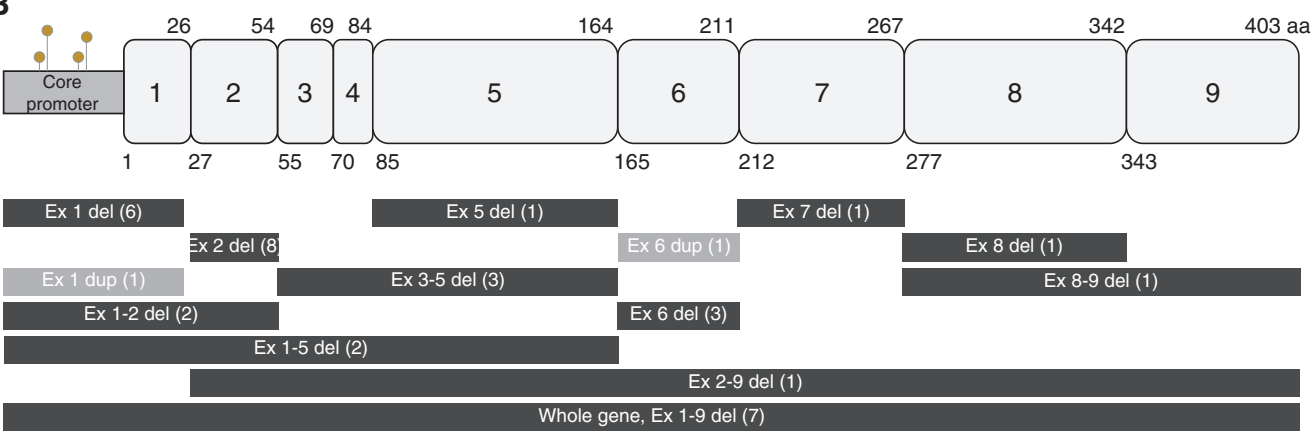

Figure 2. PTEN structure and gene mutation spectrum in PTEN hamartoma tumor syndrome (PHTS). $(A)$ Three-dimensional structure of the PTEN protein. PTEN is a 403-amino acid (aa) protein that comprises a amino-terminal region including a phosphatidylinositol 4,5-bisphosphate ( $\left.\mathrm{PIP}_{2}\right)$-binding domain (PBD) and a phosphatase domain, and a carboxy-terminal region including a $\mathrm{C} 2$ domain and a PDZ-binding domain. The active site is included between amino acid residues 123 and 130. The carboxy (C) tail contributes to PTEN stability and activity. The PDZ domain is important for protein-protein interactions that play a vital role in cellular signaling transduction. WPD loop, residues 88-98; P loop, residues 123-131; T1 loop, residues 160-171; CBR3 loop, residues 260-269; domain linker, residues 185-191. (B) PTEN germline mutation spectrum from 291 PHTS probands. PTEN consists of nine exons that encode a 403 amino acid protein. Different types of mutations are depicted in the lollipop plot overlaying the PTEN protein structure. The frequency of mutations correlates with the heights of the vertical lines representing each lollipop. The different types of mutations are color-coded as depicted in the key at the top of the figure. (From Yehia et al. 2019, with permission, from Elsevier (c) 2017.)

sible to predict at an individual level who will go on to develop any particular component cancer during his/her lifetime. Hence, multiple studies have attempted to find predictive PTEN genotype-phenotype correlations. Earlier studies revealed an association between PTEN germline mutations and malignant breast disease (Marsh et al. 1998, 1999). Missense mutations and mutations within and $5^{\prime}$ of the phosphatase core motif appear to be associated with multiorgan manifestations, serving as a surrogate of disease severity (Marsh et al. 1998). Other groups could not find such genotype-phenotype correlations (Nelen et al. 1999), although their sample size of studied PHTS patients is small $(n=13)$, compared to the 44 families and 43 probands of the preceding studies (Marsh et al. 1998, 1999). More recently, germline PTEN frameshift mutations have been found to be overrepresented, but not absolute, in thyroid cancer (Ngeow et al. 2011), nonsense mutations in colorectal cancer (Tan et al. 2012), promoter mutations in breast cancer (Tan et al. 2012), and missense mutations overrepresented in individuals with autism spectrum disorder (ASD) (Frazier et al. 2015). Interestingly, a theoretical computational approach revealed global three-dimensional PTEN structural instability and inactive conformation in 
cancer-associated PTEN mutations, whereas ASD-associated PTEN mutations revealed localized destabilization contributing to partial opening of the active site (Smith et al. 2019). Such effects cannot be extrapolated from PTEN secondary structure alone and indeed provide an important dimension to consider for assessing PTEN-genotype-PHTS-phenotype associations. Additionally, studies suggest that ASD-associated mutations tend to be less severe relative to non-ASD-associated mutations (Spinelli et al. 2015; Leslie and Longy 2016; Mighell et al. 2018). Finally, imbalances in PTEN subcellular localization could impact PHTS phenotypic manifestations. A murine model of germline-mislocalized cytoplasm-predominant Pten exhibits macrocephaly and a neurocognitive profile reminiscent of high-functioning ASD (Tilot et al. 2014 2016). Intriguingly, germline-mislocalized nuclear-predominant PTEN can exist in patients with either cancer or ASD (He et al. 2011a; Mingo et al. 2018). In this context, it is tempting to speculate whether mutant nuclear PTEN plays distinct roles in an organ-specific manner related to the seemingly disparate phenotypes.

The lack of absolute PTEN genotype-phenotype correlations suggest that additional factors act as phenotypic modifiers in PHTS. A proof-of-principle study showed that $\sim 6 \%$ of PTEN mutation-positive CS/CS-like individuals also harbor germline variants in genes encoding three of the four subunits of mitochondrial complex II ( $S D H B, S D H C$, and $S D H D)$, originally discovered as alternative susceptibility genes in PTEN wild-type CS/CS-like patients (Ni et al. 2008, 2012). Individuals carrying $S D H x$ variants show an increased risk of breast and thyroid cancers that surpass the risks mediated by mutant PTEN alone (Ni et al. 2012). Interestingly, although individuals with $\mathrm{SDHx}$ variants alone show the highest prevalence of thyroid cancer, the coexistence of a PTEN mutation was associated with a $77 \%$ snapshot prevalence of breast cancer, as compared to $32 \%$ with PTEN mutations alone and 57\% with SDHx variants alone. Although the prevalence of thyroid cancer was not significantly elevated in individuals with both PTEN mutations and SDHx variants, the histology was papillary for all tumors versus the notable enrichment in follicular thyroid tumors in individuals with only PTEN mutations. Mechanistically, $S D H x$ variants result in ROS-mediated stabilization of HIF- $1 \alpha$, destabilization and decreased protein expression of p53 due to defective interaction with NQO1, and resistance to apoptosis ( $\mathrm{Ni}$ et al. 2012). These data also reveal how mitochondrial dysfunction leads to tumorigenesis subsequent to elevated flavin adenine dinucleotide (FAD) and nicotinamide adenine dinucleotide $\left(\mathrm{NAD}^{+}\right)$, the cofactor and product of NQO1 enzymatic catalysis, respectively. Subsequent studies showed that SDHD p.G12S and p.H50R variants directly lead to impaired PTEN subcellular localization and function through SRC-induced oxidation, accompanied by apoptosis resistance and induction of cellular migration (Yu et al. 2015). Importantly, the specific SRC inhibitor bosutinib could rescue these tumorigenic phenotypes only when wild-type PTEN was present. Similarly, SDHD p.G12S and p.H50R variants result in reduced autophagy in a PTEN-dependent manner (Yu et al. 2017). These data indeed provide mechanistic insights regarding the clinically observed increased prevalence of thyroid cancer in CS patients with $S D H x$ variants alone compared to those with PTEN mutations alone, yet the seemingly paradoxical decreased prevalence of thyroid cancer in the setting of coexisting PTEN mutations and $S D H x$ variants.

Additionally, the type of germline PTEN mutation could also influence eventual cell fates. For example, germline PTEN mutations such as carboxy-terminal deletions that result in genomic instability could prime tissues that are particularly sensitive to DNA damage for progression to malignancy (Sun et al. 2014). Finally, the immune system has been recognized as a major determinant of cancer development (Cavallo et al. 2011; Michaud et al. 2015; Singh and Dorak 2017). PTEN loss promotes resistance to tumor immune cell infiltration through the production of inhibitory cytokines, hence resulting in immune escape (Peng et al. 2016). Interestingly, pregnant mice treated with lowdose lipopolysaccharide to induce maternal inflammation give offspring with brain overgrowth (Le Belle et al. 2014). This phenotype is 
more pronounced in Pten heterozygous mice compared to wild-type, indicating evident cross talk between genetic susceptibility and the inflamed microenvironment mediated through ROS signaling. Importantly, ROS cause oxidation and subsequent inactivation of PTEN, a mechanism observed in a subset of CS/CS-like patients (Kwon et al. 2004; Yu et al. 2015). Hence, the manifestation of a cancer phenotype does represent a complex interplay among predisposing factors, genetic and epigenetic confounders, tissue-specific signaling networks, oncogenic signaling pathways, and microenvironmental context (Schneider et al. 2017).

\section{PTEN AND SPORADIC CANCERS}

PTEN dysfunction in PHTS offers important biological insights in the context of common sporadic cancers. Indeed, PTEN is one of the most frequently somatically mutated genes in cancer (Cantley and Neel 1999; Simpson and Parsons 2001; Hollander et al. 2011). The Sanger Institute maintains a database of annotated PTEN mutations and 30 tumor types (see the Catalogue of Somatic Mutations in Cancer [COSMIC] website). From this database, it is clear that in sporadic tumors, mutations and small insertions and deletions occur throughout the length of PTEN. Intriguingly, despite the fact that germline PTEN mutations result in component cancers within a restricted set of organs (Tan et al. 2012), PTEN somatic driver mutations are enriched in multiple sporadic cancer types that are not components of the PHTS spectrum, including prostate cancer, glioblastoma multiforme (GBM), and others (Li et al. 1997).

\section{ROLE OF PTEN IN SPORADIC PHTS- RELATED CANCERS}

\section{Breast Cancers}

Sporadic breast tumors were found to have somatic PTEN mutations in $<5 \%$ of cases despite loss of PTEN immunoreactivity in nearly $40 \%$ (Perren et al. 1999; Perez-Tenorio et al. 2007). Promoter methylation as well as loss of heterozygosity (LOH) at 10q23 was seen in 40\%-50\% of breast cancer samples (Singh et al. 1998; Gar- cía et al. 2004). Further evidence of the role of PTEN in breast tumorigenesis is seen from mice models. Pten ${ }^{+/-}$mice develop breast tumors at high frequencies depending on their genetic background (Stambolic et al. 2000). Deletion of both Pten alleles in the mammary epithelium leads to altered mammary development and high-frequency early-onset tumors in mice (Li et al. 2002). Loss of a single Pten allele accelerated tumorigenesis in a Wnt-induced mammary tumor model and most tumors lost the remaining Pten allele (Li et al. 2001). Decreases in PTEN expression also resulted in increased risk of breast tumor formation in the absence of other induced mutations (Alimonti et al. 2010; Shen-Li et al. 2010). These models suggest that reduced PTEN expression resulted in increased tumor formation. Attenuated PTEN expression either by gene mutation, $\mathrm{LOH}$, or promoter methylation may indeed drive breast carcinogenesis, making PTEN and downstream signaling pathways potential targets for novel drug development.

\section{Thyroid Tumors}

Thyroid tumors were one of the first tumor types to be reported as associated with PHTS (Lloyd and Dennis 1963). A quarter of thyroid adenomas and several sporadic malignant thyroid cancers were found to have PTEN LOH with PTEN mutations occurring less frequently (Dahia et al. 1997; Halachmi et al. 1998). Loss of PTEN expression occurs in $<10 \%$ of thyroid cancers, but are more frequently seen in anaplastic and undifferentiated thyroid cancers (Gimm et al. 2000; Frisk et al. 2002). PTEN promoter methylation was seen in more than $50 \%$ of thyroid tumors and especially in follicular thyroid subtype with loss of PTEN immunoreactivity correlating significantly with promoter methylation (AlvarezNuñez et al. 2006).

In mice, thyroid lesions develop late and with low frequency in Pten ${ }^{+/-}$mouse models. Homozygous deletion of Pten in mouse thyroid cells did develop into benign follicular adenomas in female mice (Yeager et al. 2007). Hemizygous deletion of Pten was seen to accelerate thyroid adenocarcinoma formation when addi- 
tional genetic alterations were present: loss of p27 (Di Cristofano et al. 2001) and in the setting of mutant thyroid hormone receptor- $\beta$ (Yeager et al. 2007). Based on these mouse studies, it does appear that decreased gene dosage of PTEN is indeed important for thyroid cancer progression in the presence of other genetic alterations.

\section{Endometrial Tumors}

Sporadic mutations in PTEN are seen in 35\%$50 \%$ of endometrial carcinomas and also in endometrial hyperplasias, which is believed to be a precursor for endometrial carcinomas (Risinger et al. 1997, 1998; Tashiro et al. 1997; Maxwell et al. 1998a,b; Mutter et al. 2000). The majority of the tumors demonstrate insertion or deletion frameshift mutations that result in microsatellite instability, suggesting that PTEN's role in endometrial carcinogenesis may lie in its impact on DNA repair mechanisms. Interestingly, altered PTEN expression can be noted, and may act as a biomarker of endometrial precancers (Mutter et al. 2000) and even latent precancers in histologically normal-appearing endometrium (Mutter et al. 2001).

In mice, Pten ${ }^{+/-}$mice can develop endometrial hyperplasia with high penetrance with clear progression into endometrial carcinomas (Stambolic et al. 2000). The role of DNA repair in the maintenance of PTEN integrity is also highlighted in mouse models of endometrial cancer. Deletion of Mlh1 in Pten ${ }^{+/-}$mice accelerates endometrial carcinoma formation and was associated with earlier LOH of remaining Pten allele (Wang et al. 2002). This is corroborated in microsatellite unstable (hallmark of mismatch repair deficiency) versus stable human colorectal cancers, whereby all the former tumors with somatic PTEN mutations occur in the two poly(A) coding mononucleotide tracts, suggesting that mismatch repair preceded and is etiologic for somatic PTEN mutations (Zhou et al. 2002).

\section{Melanoma}

Sporadic melanomas frequently have a loss of PTEN through $\mathrm{LOH}$, deletion, and mutation
(Trotman and Pandolfi 2003). PTEN can also be epigenetically silenced in melanoma, as decreased PTEN transcript levels were associated with PTEN promoter methylation (Mirmohammadsadegh et al. 2006). In mice, Pten deletion in pigmented mouse cells does not lead to the development of melanomas but did increase the number of melanocytes that led to melanoma formation in half of the samples when topical carcinogen was added (Mirmohammadsadegh et al. 2006). In the presence of other genetic alterations such as BRAF and Cdkn2a, Pten can contribute to the malignant phenotype (You et al. 2002; Dankort et al. 2009).

\section{OTHER CANCERS NOT CLASSICALLY ASSOCIATED WITH PHTS}

\section{Brain Tumors}

PTEN loss is seen in both benign and malignant brain tumors. Lhermitte-Dulcos disease (LDD) is a rare benign tumor that occurs in CS (Marsh et al. 1999; Zhou et al. 2003a; Gustafson et al. 2007, but gliomas are never seen in PHTS. In GBMs, sporadic PTEN mutations are found in $>40 \%$ of tumors and PTEN LOH in 70\% (Wang et al. 1997). As seen with other cancers, the level of PTEN expression is again seen to impact on tumorigenesis and grade of tumors. Decreased PTEN expression is characteristic of tumor progression with lower-grade gliomas expressing higher PTEN expression (Sano et al. 1999; Schmidt et al. 1999). Higher PTEN expression also correlated with better survival (Sano et al. 1999). Recently, miR-26a, which targets PTEN mRNA for degradation, was amplified in glioma and found to be associated with PTEN LOH (Huse et al. 2009), further strengthening the case that attenuation of PTEN expression results if there is increased cell proliferation. Pten ${ }^{+/-}$ mice do not develop brain tumors but homozygous deletions of Pten have resulted in changes that resemble LDD (Backman et al. 2001; Kwon et al. 2001). Pten deletion in the face of other genetic alterations also accelerated glioma formation (Xiao et al. 2002; Wei et al. 2006). Indeed, inhibition of fibroblast growth factor receptor (FGFR)-mediated tyrosine (Y24o) 
phosphorylation on nuclear PTEN has been shown to enhance radiation sensitivity in GBM by attenuating DNA repair via RAD51 (Ma et al. 2019).

\section{Prostate Cancers}

Prostate carcinoma is never seen in males with PHTS. One of the early cytogenetic abnormalities identified in prostate cancer was the deletion of chromosome 10q, and subsequently PTEN loss in primary prostate cancer was mapped to this region (Lundgren et al. 1988; Cairns et al. 1997). Homozygous deletion of Pten in the mouse prostate led to prostatic intraepithelial neoplasia (PIN) lesions at 6 weeks of age that progressed to invasive and metastatic prostate carcinoma within a few weeks (Wang et al. 2003). As we saw in other tumor types, concurrent Pten hemizygosity coupled with deletions in other genes accelerated tumorigenesis (Di Cristofano et al. 2001; Abate-Shen et al. 2003). Tmprss2-Erg translocation was seen in mice to cooperate with Pten hemizygosity to promote malignant progression (Carver et al. 2009; King et al. 2009). Pten hypomorphic alleles with lower PTEN expression levels correlated with increased progression of prostate cancer in the mouse, suggesting the Pten may be haplosufficient for prostate tumorigenesis and/or prostate tumor progression (Trotman et al. 2003).

\section{Lung Cancer}

Lung cancer is not a feature of CS and sporadic PTEN mutations are not seen frequently. It appears that other mechanisms are affecting PTEN expression in lung cancer. PTEN expression is reduced in $24 \%$ of early non-small-cell lung cancer associated with promoter methylation (Sos et al. 2009). In another study, $>70 \%$ of lung tumors were associated with low or aberrant TP53 staining (Sos et al. 2009). Levels of miR-21 were up-regulated in lung tumors compared with normal lung tissue in $>70 \%$ of cases, which was correlated with decreased levels of PTEN mRNA levels and advanced tumor stage (Zhang et al. 2010). PTEN is also thought to modulate lung cancer resistance to epidermal growth factor receptor (EGFR) inhibitors by activation of AKT and EGFR (Sos et al. 2009). Pten ${ }^{+/-}$mice have not been reported to develop lung tumors. Homozygous deletions in Pten in alveolar cells led to adenocarcinoma in $87 \%$ of mice by 70 weeks of age (Yanagi et al. 2007).

\section{Pancreatic Cancer}

Pancreatic cancer is not associated with CS, and mutations in PTEN are rare in sporadic pancreatic cancers. In mice, heterozygous deletion of Pten in the pancreas leads to metaplasia that progresses to pancreatic cancer in $~ 20 \%$ of mice (Stanger et al. 2005). However, codeletion of Smad4, the common mediator of signal transduction, does lead to tumor formation, with increased AKT and mTOR signaling (Xu et al. 2010).

\section{TARGETING PTEN FOR CANCER TREATMENT}

Altered PI3K/AKT/mTOR signaling in the PTEN-opathies implies that PI3K, AKT, and mTOR inhibitors are germane targets for therapeutic intervention. Because PHTS patients harbor identifiable PTEN germline mutations, the $\mathrm{PI} 3 \mathrm{~K} / \mathrm{AKT} / \mathrm{mTOR}$ signaling pathway is no longer negatively regulated by PTEN. Therefore, these patients theoretically represent ideal candidates for molecularly targeted pathway inhibition. Proof-of-principle case reports demonstrate the utilization of the mTOR inhibitor rapamycin to alleviate the symptoms and overgrowth manifestations of a child suffering from PTEN-related Proteus syndrome (Marsh et al. 2008) and a PHTS infant suffering from Lhermitte-Duclos disease (Zak et al. 2017). Indeed, the mTOR inhibitor sirolimus has been used in a phase II open label clinical trial in individuals with PHTS (NCT00971789), with an ongoing collection of follow-up data and analysis. Because individuals with PHTS also have neurodevelopmental disorders, a double-blind drug-placebo, crossover trial with the mTOR inhibitor everolimus is currently accruing pedi- 
atric, adolescent, and young adult PHTS patients with ASD (Eng 2016).

Upstream components of the PTEN signaling pathway, such as PI3K and AKT inhibitors, also serve as candidates for pharmacologic inhibition. As such, AKT and PIK3CA inhibitors have been utilized in PS and PIK3CA-related overgrowth spectrum (PROS) disorders (Lindhurst et al. 2015; Ranieri et al. 2018; Venot et al. 2018).

Another major caveat for molecularly targeting the $\mathrm{PI} 3 \mathrm{~K} / \mathrm{AKT} / \mathrm{mTOR}$ pathway is feedback activation of collateral oncogenic signaling pathways, causing resistance. This led to the investigation of combinatorial therapies that would, in theory, effectively target the growthpromoting signals, without loss of feedback controls. Indeed, inhibiting mTOR has been shown to result in feedback activation of upstream signaling components such as AKT through insulin receptor substrate 1 (IRS1) or through direct phosphorylation at Ser473 by mTORC2 (Mahalingam et al. 2009). However, experimental studies show promise in that the rebound upregulation of AKT during mTOR inhibition can be abrogated by pretreatment or cotreatment with Resveratrol, at least in vitro ( $\mathrm{He}$ et al 2011b). Moreover, PI3K inhibition can result in therapeutic resistance in PIK3CA mutant cell lines as a result of a rebound insulin-dependent feedback mechanism (Hopkins et al. 2018) or failure to suppress CDK $4 / 6$ as evidenced through persistent RB phosphorylation (Vora et al. 2014). In these contexts, the combination of various PI3K inhibitors with antiglycemic therapies or CDK 4/6 inhibitors, respectively, results in the attenuation of the progrowth feedback signaling cascades, hence overcoming resistance. Interestingly, NVP-BEZ235, a dual $\mathrm{PI} 3 \mathrm{~K} / \mathrm{mTOR}$ inhibitor, has been shown to selectively inhibit the growth of a subset of androgen receptor-positive $\left(\mathrm{AR}^{+}\right)$breast cancer cell lines (Wang et al. 2014). AR is positively correlated with PTEN expression in breast cancer, resulting from direct $P T E N$ transcription, mediated by an androgen response element (ARE) in the PTEN promoter (Wang et al. 2011, 2012). Mechanistically, the beneficial effect of AR activation in combination with $\mathrm{PI} 3 \mathrm{~K} / \mathrm{AKT} / \mathrm{mTOR}$ inhibition in $\mathrm{AR}^{+} / \mathrm{ER}^{+}$breast cancers can be explained, at least partially, through PTEN up-regulation and suppression (Wang et al. 2014).

A novel approach could be to target the vulnerabilities caused by patient-specific germline PTEN mutations. For example, because PTEN plays a vital role in maintaining genomic integrity in the nucleus, it is possible to therapeutically use PARP inhibitors (Dillon and Miller 2014). Moreover, patients with germline PTEN mutations within the carboxy-terminal region could benefit from proteasome inhibitors to mitigate PTEN degradation (Georgescu et al. 1999). Indeed, treatment with the proteasome inhibitor MG-132 can restore both nonsense and missense mutant PTEN protein levels in vitro (He et al. 2013). However, restoring missense mutant PTEN levels in the presence of the wild-type allele can result in dominant-negative effects and could worsen the condition (Papa et al. 2014). Predictably, in the era of precision medicine, cancer prevention is key and determining context-specific therapeutic indices will be vital for the effective management of PHTS.

\section{IMMUNOTHERAPY}

Immune checkpoint monoclonal antibody blockades, such as programmed cell death 1 (PD-1) inhibitors, have led to remarkable and durable antitumor effects in multiple cancer types, including melanoma and non-small-cell lung cancer (Cheng et al. 2019). The PI3K/AKT/ mTOR pathway is an important regulator of immunity (Okkenhaug 2013; Chen et al. 2017a). Because PTEN is a master regulator of this pathway, it is therefore not surprising that PTEN disruption can result in immune dysregulation. The latter is germane in carcinogenesis, whereby immune surveillance, evasion of immune recognition, and a chronically inflamed microenvironment represent major immune hallmarks of cancer (Cavallo et al. 2011). However, GBM patients respond poorly to immunotherapy, and the molecular determinants in the resistance mechanisms to this immunotherapy are poorly characterized. A recent longitudinal study was performed comprising $66 \mathrm{GBM}$ pa- 
tients during standard therapy and after antiPD-1 immunotherapies, including 17 longterm responders who showed durable responses to therapy (Zhao et al. 2019). Via whole-exome sequencing analysis, they found that somatic PTEN mutations were significantly enriched in nonresponders after correcting the background mutation rate derived from The Cancer Genome Atlas (TCGA). By individual sample gene-set enrichment analysis, the authors showed significantly elevated PI3K-AKT pathway activity in nonresponsive tumors with PTEN somatic mutations (Zhao et al. 2019). To investigate the resistance mechanism of PTEN mutations further, they inspected the single-cell RNAsequencing profiles across 9000 cells in three GBM patients, including one PTEN-mutant sample. They found that cells associated with immune signatures were significantly enriched in the PTEN-mutant tumor. They further identified three major types of cell subpopulations: tumor cells with migration markers $\left(\mathrm{CD} 44^{+}\right)$, actively proliferating tumor cells, and microglia. As expected, the immunosuppressive signature was significantly associated with the CD $44^{+}$tumor cell subpopulations in the PTEN-mutant tumor, indicating that PTEN mutations may play a crucial role in the immune microenvironment and influence resistance to immunotherapy. This study suggests that PTEN mutations are significantly enriched in nonresponders to anti-PD-1 inhibitors, offering a potential personalized immunotherapy approach for GBM. By integrating bulk RNA-seq and published single-cell RNA-seq data analysis, the authors further showed that PTEN mutations may lead to a distinct immunosuppressive microenvironment, which helps to explain the resistance mechanisms to immunotherapy.

Additionally, PI3K/AKT/mTOR pathway activation has been shown to modulate responses to immunotherapy. Loss of PTEN in the sporadic context has been associated with resistance to anti-PD-1 therapy in melanoma (Peng et al. 2016), a CS component cancer, and, more recently, a case study of metastatic uterine leiomyosarcoma (George et al. 2017). Interestingly, activation of the PI3K/AKT/ mTOR pathway has been shown to drive expres- sion of PD-1/PD-L1 in a subset of solid tumors, causing immunoresistance (Parsa et al. 2007; Crane et al. 2009; Lastwika et al. 2016). Indeed, because PTEN seems to be a major immunotherapeutic response predictor, multiple questions arise regarding the promising utility of immunotherapeutic agents in individuals with germline PTEN mutations and cancer. Studies have shown that a subset of individuals with PHTS have autoimmune phenotypes, and Band T-cell-related immune dysfunctions (Heindl et al. 2012; Chen et al. 2017a; see Taylor et al. 2019). Importantly, reduction in peripheral lymphocyte numbers compared to control subjects, including decreased $\mathrm{CD} 4^{+}$cell numbers and hence absolute FOXP3 ${ }^{+}$Treg (regulatory T) cell numbers would suggest that these individuals will have a different response to immunotherapy compared to individuals with normal immune systems.

\section{CONCLUSIONS}

One of the most serious complications of PHTS is the increased lifetime risk for cancer. Although PTEN-enabled organ-specific cancer risk estimates and management guidelines are part of the routine clinical armamentarium of precision care, it remains virtually impossible to absolutely predict which individual (versus a probability) will develop which component malignancy. Identical germline PTEN mutations are observed in patients with these seemingly disparate phenotypes (e.g., cancer vs. ASD), indicating that additional factors may act as phenotypic modifiers in PHTS. Hence, future studies elucidating absolute modifiers of disease manifestations and associated signaling networks will be key to define more precise and effective preventative and therapeutic strategies for the individual at risk. Greater understanding of the different mechanisms underlying PTEN loss will undoubtedly refine the ability to more optimally treat patients. It will be exciting to see further studies examining the interaction of PTEN with other tumor suppressors or oncogenes as well as how how we may exploit the phosphatase-dependent and phosphatase-independent functions of PTEN for treatment. 


\section{COMPETING INTEREST STATEMENT}

The authors have declared that no relevant conflicts of interest exist.

\section{ACKNOWLEDGMENTS}

We are grateful to our patients and their families who have participated in our research studies for over two decades. C.E. is the Sondra J. and Stephen R. Hardis Chair of Cancer Genomic Medicine at the Cleveland Clinic and an American Cancer Society Clinical Research Professor.

\section{REFERENCES \\ ${ }^{*}$ Reference is also in this collection.}

Abate-Shen C, Banach-Petrosky WA, Sun X, Economides KD, Desai N, Gregg JP, Borowsky AD, Cardiff RD, Shen MM. 2003. Nkx3.1; Pten mutant mice develop invasive prostate adenocarcinoma and lymph node metastases. Cancer Res 63: 3886-3890.

Alimonti A, Carracedo A, Clohessy JG, Trotman LC, Nardella C, Egia A, Salmena L, Sampieri K, Haveman WJ, Brogi E, et al. 2010. Subtle variations in Pten dose determine cancer susceptibility. Nat Genet 42: 454-458. doi:10 $.1038 / \mathrm{ng} .556$

Alvarez-Nuñez F, Bussaglia E, Mauricio D, Ybarra J, Vilar M, Lerma E, de Leiva A, Matias-Guiu X. 2006. PTEN promoter methylation in sporadic thyroid carcinomas. Thy roid 16: 17-23. doi:10.1089/thy.2006.16.17

Backman SA, Stambolic V, Suzuki A, Haight J, Elia A, Pretorius J, Tsao MS, Shannon P, Bolon B, Ivy GO, et al. 2001 Deletion of Pten in mouse brain causes seizures, ataxia and defects in soma size resembling Lhermitte-Duclos disease. Nat Genet 29: 396-403. doi:10.1038/ng782

Baker SJ. 2007. PTEN enters the nuclear age. Cell 128: 25-28. doi:10.1016/j.cell.2006.12.023

Bubien V, Bonnet F, Brouste V, Hoppe S, Barouk-Simonet E, David A, Edery P, Bottani A, Layet V, Caron O, et al. 2013. High cumulative risks of cancer in patients with PTEN hamartoma tumour syndrome. J Med Genet 50: 255-263. doi:10.1136/jmedgenet-2012-101339

Cairns P, Okami K, Halachmi S, Halachmi N, Esteller M, Herman JG, Jen J, Isaacs WB, Bova GS, Sidransky D. 1997. Frequent inactivation of PTEN/MMAC1 in primary prostate cancer. Cancer Res 57: 4997-5000.

Cano CE, Gommeaux J, Pietri S, Culcasi M, Garcia S, Seux M, Barelier S, Vasseur S, Spoto RP, Pebusque MJ, et al. 2009. Tumor protein 53 -induced nuclear protein 1 is a major mediator of p53 antioxidant function. Cancer Res 69: 219-226. doi:10.1158/0008-5472.CAN-08-2320

Cantley LC, Neel BG. 1999. New insights into tumor suppression: PTEN suppresses tumor formation by restraining the phosphoinositide 3-kinase/AKT pathway. Proc Natl Acad Sci 96: 4240-4245. doi:10.1073/pnas.96.8.4240
Carver BS, Tran J, Gopalan A, Chen Z, Shaikh S, Carracedo A, Alimonti A, Nardella C, Varmeh S, Scardino PT, et al. 2009. Aberrant ERG expression cooperates with loss of PTEN to promote cancer progression in the prostate. Nat Genet 41: 619-624. doi:10.1038/ng.370

Cavallo F, De Giovanni C, Nanni P, Forni G, Lollini PL. 2011. 2011: The immune hallmarks of cancer. Cancer Immunol Immunother 60: 319-326. doi:10.1007/s00 262-010-0968-0

Chen ZH, Zhu M, Yang J, Liang H, He J, He S, Wang P, Kang X, McNutt MA, Yin Y, et al. 2014. PTEN interacts with histone $\mathrm{H} 1$ and controls chromatin condensation. Cell Rep 8: 2003-2014. doi:10.1016/j.celrep.2014.08.008

Chen HH, Handel N, Ngeow J, Muller J, Hühn M, Yang HT, Heindl M, Berbers RM, Hegazy AN, Kionke J, et al. 2017a. Immune dysregulation in patients with PTEN hamartoma tumor syndrome: analysis of FOXP3 regulatory T cells. J Allergy Clin Immunol 139: 607-620.e15. doi:10 .1016/j.jaci.2016.03.059

Chen HJ, Romigh T, Sesock K, Eng C. 2017b. Characterization of cryptic splicing in germline PTEN intronic variants in Cowden syndrome. Hum Mutat 38: 1372-1377. doi:10.1002/humu.23288

Cheng F, Liang H, Butte AJ, Eng C, Nussinov R. 2019. Personal mutanomes meet modern oncology drug discovery and precision health. Pharmacol Rev 71: 1-19. doi:10 $.1124 /$ pr.118.016253

Cohen MM Jr, Hayden PW. 1979. A newly recognized hamartomatous syndrome. Birth Defects Orig Artic Ser 15: 291-296.

Crane CA, Panner A, Murray JC, Wilson SP, Xu H, Chen L, Simko JP, Waldman FM, Pieper RO, Parsa AT. 2009. PI(3) kinase is associated with a mechanism of immunoresistance in breast and prostate cancer. Oncogene 28: 306312. doi:10.1038/onc.2008.384

Crivelli L, Bubien V, Jones N, Chiron J, Bonnet F, BaroukSimonet E, Couzigou P, Sevenet N, Caux F, Longy M. 2017. Insertion of Alu elements at a PTEN hotspot in Cowden syndrome. Eur J Hum Genet 25: 1087-1091. doi:10.1038/ejhg.2017.81

Dahia PL, Marsh DJ, Zheng Z, Zedenius J, Komminoth P, Frisk T, Wallin G, Parsons R, Longy M, Larsson C, et al. 1997. Somatic deletions and mutations in the Cowden disease gene, PTEN, in sporadic thyroid tumors. Cancer Res 57: 4710-4713.

Dankort D, Curley DP, Cartlidge RA, Nelson B, Karnezis AN, Damsky WE Jr, You MJ, DePinho RA, McMahon M, Bosenberg M. 2009. Braf(V600E) cooperates with Pten loss to induce metastatic melanoma. Nat Genet 41: 544552. doi:10.1038/ng.356

Davidson L, Maccario H, Perera NM, Yang X, Spinelli L, Tibarewal P, Glancy B, Gray A, Weijer CJ, Downes CP, et al. 2010. Suppression of cellular proliferation and invasion by the concerted lipid and protein phosphatase activities of PTEN. Oncogene 29: 687-697. doi:10.1038/ onc.2009.384

Di Cristofano A, Pesce B, Cordon-Cardo C, Pandolfi PP. 1998. Pten is essential for embryonic development and tumour suppression. Nat Genet 19: 348-355. doi:10 $.1038 / 1235$

Di Cristofano A, De Acetis M, Koff A, Cordon-Cardo C, Pandolfi PP. 2001. Pten and p27KIP1 cooperate in pros- 
tate cancer tumor suppression in the mouse. Nat Genet 27: 222-224. doi:10.1038/84879

Dillon LM, Miller TW. 2014. Therapeutic targeting of cancers with loss of PTEN function. Curr Drug Targets 15: 65-79. doi:10.2174/1389450114666140106100909

Eng C. 2003. PTEN: One gene, many syndromes. Hum Mutat 22: 183-198. doi:10.1002/humu.10257

Eng C. 2016. PTEN hamartoma tumor syndrome. In Gene Reviews (eds. Pagon RA, et al.). University of Washington, Seattle, WA.

Frazier TW, Embacher R, Tilot AK, Koenig K, Mester J, Eng C. 2015. Molecular and phenotypic abnormalities in individuals with germline heterozygous PTEN mutations and autism. Mol Psychiatry 20: 1132-1138. doi:10.1038/ mp.2014.125

Frisk T, Foukakis T, Dwight T, Lundberg J, Höög A, Wallin G, Eng C, Zedenius J, Larsson C. 2002. Silencing of the PTEN tumor-suppressor gene in anaplastic thyroid cancer. Genes Chromosomes Cancer 35: 74-80. doi:10.1002/ gcc. 10098

Furnari FB, Lin H, Huang HS, Cavenee WK. 1997. Growth suppression of glioma cells by PTEN requires a functional phosphatase catalytic domain. Proc Natl Acad Sci 94: 12479-12484. doi:10.1073/pnas.94.23.12479

García JM, Silva J, Peña C, Garcia V, Rodríguez R, Cruz MA, Cantos B, Provencio M, España P, Bonilla F. 2004. Promoter methylation of the PTEN gene is a common molecular change in breast cancer. Genes Chromosomes Cancer 41: 117-124. doi:10.1002/gcc.20062

George S, Miao D, Demetri GD, Adeegbe D, Rodig SJ, Shukla S, Lipschitz M, Amin-Mansour A, Raut CP, Carter SL, et al. 2017. Loss of PTEN is associated with resistance to anti-PD-1 checkpoint blockade therapy in metastatic uterine leiomyosarcoma. Immunity 46: 197-204. doi:10 .1016/j.immuni.2017.02.001

Georgescu MM, Kirsch KH, Akagi T, Shishido T, Hanafusa H. 1999. The tumor-suppressor activity of PTEN is regulated by its carboxyl-terminal region. Proc Natl Acad Sci 96: 10182-10187. doi:10.1073/pnas.96.18.10182

Gimm O, Perren A, Weng LP, Marsh DJ, Yeh JJ, Ziebold U, Gil E, Hinze R, Delbridge L, Lees JA, et al. 2000. Differential nuclear and cytoplasmic expression of PTEN in normal thyroid tissue, and benign and malignant epithelial thyroid tumors. Am J Pathol 156: 1693-1700. doi:10 .1016/S0002-9440(10)65040-7

Gorlin RJ, Cohen MM Jr, Condon LM, Burke BA. 1992. Bannayan-Riley-Ruvalcaba syndrome. Am J Med Genet 44: 307-314. doi:10.1002/ajmg.1320440309

Gustafson S, Zbuk KM, Scacheri C, Eng C. 2007. Cowden syndrome. Semin Oncol 34: 428-434. doi:10.1053/j .seminoncol.2007.07.009

Halachmi N, Halachmi S, Evron E, Cairns P, Okami K, Saji M, Westra WH, Zeiger MA, Jen J, Sidransky D. 1998. Somatic mutations of the PTEN tumor suppressor gene in sporadic follicular thyroid tumors. Genes Chromosomes Cancer 23: 239-243. doi:10.1002/(SICI)10982264(199811)23:3<239::AID-GCC5>3.0.CO;2-2

He X, Ni Y, Wang Y, Romigh T, Eng C. 2011a. Naturally occurring germline and tumor-associated mutations within the ATP-binding motifs of PTEN lead to oxidative damage of DNA associated with decreased nuclear p53. Hum Mol Genet 20: 80-89. doi:10.1093/hmg/ddq434
He X, Wang Y, Zhu J, Orloff M, Eng C. 2011b. Resveratrol enhances the anti-tumor activity of the mTOR inhibitor rapamycin in multiple breast cancer cell lines mainly by suppressing rapamycin-induced AKT signaling. Cancer Lett 301: 168-176. doi:10.1016/j.canlet.2010.11.012

He X, Arrotta N, Radhakrishnan D, Wang Y, Romigh T, Eng C. 2013. Cowden syndrome-related mutations in PTEN associate with enhanced proteasome activity. Cancer Res 73: 3029-3040. doi:10.1158/0008-5472.CAN-12-3811

Heindl M, Händel N, Ngeow J, Kionke J, Wittekind C, Kamprad M, Rensing-Ehl A, Ehl S, Reifenberger J, Loddenkemper C, et al. 2012. Autoimmunity, intestinal lymphoid hyperplasia, and defects in mucosal B-cell homeostasis in patients with PTEN hamartoma tumor syndrome. Gastroenterology 142: 1093-1096.e6. doi:10.1053/ j.gastro.2012.01.011

Hollander MC, Blumenthal GM, Dennis PA. 2011. PTEN loss in the continuum of common cancers, rare syndromes and mouse models. Nat Rev Cancer 11: 289301. doi: $10.1038 / \mathrm{nrc} 3037$

Hopkins BD, Pauli C, Du X, Wang DG, Li X, Wu D, Amadiume SC, Goncalves MD, Hodakoski C, Lundquist MR, et al. 2018. Suppression of insulin feedback enhances the efficacy of PI3K inhibitors. Nature 560: 499-503. doi:10 .1038/s41586-018-0343-4

Huse JT, Brennan C, Hambardzumyan D, Wee B, Pena J, Rouhanifard SH, Sohn-Lee C, le Sage C, Agami R, Tuschl T, et al. 2009. The PTEN-regulating microRNA miR-26a is amplified in high-grade glioma and facilitates gliomagenesis in vivo. Genes Dev 23: 1327-1337. doi:10.1101/ gad.1777409

Inoki K, Li Y, Zhu T, Wu J, Guan KL. 2002. TSC2 is phosphorylated and inhibited by Akt and suppresses mTOR signalling. Nat Cell Biol 4: 648-657. doi:10.1038/ncb839

King JC, Xu J, Wongvipat J, Hieronymus H, Carver BS, Leung DH, Taylor BS, Sander C, Cardiff RD, Couto SS, et al. 2009. Cooperativity of TMPRSS2-ERG with PI3kinase pathway activation in prostate oncogenesis. Nat Genet 41: 524-526. doi:10.1038/ng.371

Kirk EP, Smith JM, Field M, Marshall GM, Marsh DJ. 2004. Diagnosis of Proteus syndrome was correct. Am J Med Genet A 130A: 214-215. Author reply 216-217. doi:10 .1002/ajmg.a.30337

Kwon CH, Zhu X, Zhang J, Knoop LL, Tharp R, Smeyne RJ, Eberhart CG, Burger PC, Baker SJ. 2001. Pten regulates neuronal soma size: a mouse model of Lhermitte-Duclos disease. Nat Genet 29: 404-411. doi:10.1038/ng781

Kwon J, Lee SR, Yang KS, Ahn Y, Kim YJ, Stadtman ER, Rhee SG. 2004. Reversible oxidation and inactivation of the tumor suppressor PTEN in cells stimulated with peptide growth factors. Proc Natl Acad Sci 101: 16419-16424. doi:10.1073/pnas.0407396101

Lastwika KJ, Wilson W III, Li QK, Norris J, Xu H, Ghazarian SR, Kitagawa H, Kawabata S, Taube JM, Yao S, et al. 2016. Control of PD-L1 expression by oncogenic activation of the AKT-mTOR pathway in non-small-cell lung cancer. Cancer Res 76: 227-238. doi:10.1158/0008-5472.CAN14-3362

Le Belle JE, Sperry J, Ngo A, Ghochani Y, Laks DR, LópezAranda M, Silva AJ, Kornblum HI. 2014. Maternal inflammation contributes to brain overgrowth and autism-associated behaviors through altered redox signaling 
in stem and progenitor cells. Stem Cell Rep 3: 725-734 doi:10.1016/j.stemcr.2014.09.004

* Lee M, Trotman L. 2019. PTEN and endocytosis. Cold Spring Harb Perspect Med doi:10.1101/cshperspect.a036103

Lee YR, Chen M, Pandolfi PP. 2018. The functions and regulation of the PTEN tumour suppressor: new modes and prospects. Nat Rev Mol Cell Biol 19: 547-562. doi:10 .1038/s41580-018-0015-0

Leslie NR, Longy M. 2016. Inherited PTEN mutations and the prediction of phenotype. Semin Cell Dev Biol 52: 3038. doi:10.1016/j.semcdb.2016.01.030

Li DM, Sun H. 1997. TEP1, encoded by a candidate tumor suppressor locus, is a novel protein tyrosine phosphatase regulated by transforming growth factor $\beta$. Cancer Res $\mathbf{5 7}$ : 2124-2129.

Li J, Yen C, Liaw D, Podsypanina K, Bose S, Wang SI, Puc J, Miliaresis C, Rodgers L, McCombie R, et al. 1997. PTEN, a putative protein tyrosine phosphatase gene mutated in human brain, breast, and prostate cancer. Science 275: 1943-1947. doi:10.1126/science.275.5308.1943

Li Y, Podsypanina K, Liu X, Crane A, Tan LK, Parsons R, Varmus HE. 2001. Deficiency of Pten accelerates mammary oncogenesis in MMTV-Wnt-1 transgenic mice. BMC Mol Biol 2: 2. doi:10.1186/1471-2199-2-2

Li G, Robinson GW, Lesche R, Martinez-Diaz H, Jiang Z, Rozengurt N, Wagner KU, Wu DC, Lane TF, Liu X, et al. 2002. Conditional loss of PTEN leads to precocious development and neoplasia in the mammary gland. Development 129: 4159-4170.

Liaw D, Marsh DJ, Li J, Dahia PL, Wang SI, Zheng Z, Bose S, Call KM, Tsou HC, Peacocke M, et al. 1997. Germline mutations of the PTEN gene in Cowden disease, an inherited breast and thyroid cancer syndrome. Nat Genet 16: 64-67. doi:10.1038/ng0597-64

Lindhurst MJ, Yourick MR, Yu Y, Savage RE, Ferrari D, Biesecker LG. 2015. Repression of AKT signaling by ARQ 092 in cells and tissues from patients with Proteus syndrome. Sci Rep 5: 17162. doi:10.1038/srep17162

Lloyd KM II, Dennis M. 1963. Cowden's disease. A possible new symptom complex with multiple system involvement. Ann Intern Med 58: 136-142. doi:10.7326/00034819-58-1-136

Lobo GP, Waite KA, Planchon SM, Romigh T, Houghton JA, Eng C. 2008. ATP modulates PTEN subcellular localization in multiple cancer cell lines. Hum Mol Genet 17: 2877-2885. doi:10.1093/hmg/ddn185

Lobo GP, Waite KA, Planchon SM, Romigh T, Nassif NT, Eng C. 2009. Germline and somatic cancer-associated mutations in the ATP-binding motifs of PTEN influence its subcellular localization and tumor suppressive function. Hum Mol Genet 18: 2851-2862. doi:10.1093/hmg/ ddp220

Loffeld A, McLellan NJ, Cole T, Payne SJ, Fricker D, Moss C. 2006. Epidermal naevus in Proteus syndrome showing loss of heterozygosity for an inherited PTEN mutation. Br J Dermatol 154: 1194-1198. doi:10.1111/j.1365-2133 .2006.07196.x

Lundgren R, Kristoffersson U, Heim S, Mandahl N, Mitelman F. 1988. Multiple structural chromosome rearrangements, including del(7q) and del(10q), in an adenocarcinoma of the prostate. Cancer Genet Cytogenet 35: 103108. doi:10.1016/0165-4608(88)90128-8
Ma J, Benitez JA, Li J, Miki S, de Albuquerque C P, Galatro T, Orellana L, Zanca C, Reed R, Boyer A, et al. 2019. Inhibition of nuclear PTEN tyrosine phosphorylation enhances glioma radiation sensitivity through attenuated DNA repair. Cancer Cell 35: 816. doi:10.1016/j.ccell .2019.04.011

Maehama T, Dixon JE. 1998. The tumor suppressor, PTEN/ MMAC1, dephosphorylates the lipid second messenger, phosphatidylinositol 3,4,5-trisphosphate. J Biol Chem 273: 13375-13378. doi:10.1074/jbc.273.22.13375

Mahalingam D, Sankhala K, Mita A, Giles FJ, Mita MM. 2009. Targeting the mTOR pathway using deforolimus in cancer therapy. Future Oncol 5: 291-303. doi:10 $.2217 /$ fon. 09.9

Marsh DJ, Coulon V, Lunetta KL, Rocca-Serra P, Dahia PL, Zheng Z, Liaw D, Caron S, Duboue B, Lin AY, et al. 1998. Mutation spectrum and genotype-phenotype analyses in Cowden disease and Bannayan-Zonana syndrome, two hamartoma syndromes with germline PTEN mutation. Hum Mol Genet 7: 507-515. doi:10.1093/hmg/7.3.507

Marsh DJ, Kum JB, Lunetta KL, Bennett MJ, Gorlin RJ, Ahmed SF, Bodurtha J, Crowe C, Curtis MA, Dasouki $\mathrm{M}$, et al. 1999. PTEN mutation spectrum and genotypephenotype correlations in Bannayan-Riley-Ruvalcaba syndrome suggest a single entity with Cowden syndrome. Hum Mol Genet 8: 1461-1472. doi:10.1093/hmg/8.8.1461

Marsh DJ, Trahair TN, Martin JL, Chee WY, Walker J, Kirk EP, Baxter RC, Marshall GM. 2008. Rapamycin treatment for a child with germline PTEN mutation. Nat Clin Pract Oncol 5: 357-361. doi:10.1038/ncponc1112

Maxwell GL, Risinger JI, Gumbs C, Shaw H, Bentley RC, Barrett JC, Berchuck A, Futreal PA. 1998a. Mutation of the PTEN tumor suppressor gene in endometrial hyperplasias. Cancer Res 58: 2500-2503.

Maxwell GL, Risinger JI, Tong B, Shaw H, Barrett JC, Berchuck A, Futreal PA. 1998b. Mutation of the PTEN tumor suppressor gene is not a feature of ovarian cancers. Gynecol Oncol 70: 13-16. doi:10.1006/gyno.1998.5039

Mester J, Eng C. 2013. When overgrowth bumps into cancer: the PTEN-opathies. Am J Med Genet C Semin Med Genet 163C: 114-121. doi:10.1002/ajmg.c.31364

Michaud DS, Houseman EA, Marsit CJ, Nelson HH, Wiencke JK, Kelsey KT. 2015. Understanding the role of the immune system in the development of cancer: new opportunities for population-based research. Cancer Epidemiol Biomarkers Prev 24: 1811-1819. doi:10.1158/ 1055-9965.EPI-15-0681

Mighell TL, Evans-Dutson S, O’Roak BJ. 2018. A saturation mutagenesis approach to understanding PTEN lipid phosphatase activity and genotype-phenotype relationships. Am J Hum Genet 102: 943-955. doi:10.1016/j .ajhg.2018.03.018

Mingo J, Rodríguez-Escudero I, Luna S, Fernández-Acero T, Amo L, Jonasson AR, Zori RT, López JI, Molina M, Cid VJ, et al. 2018. A pathogenic role for germline PTEN variants which accumulate into the nucleus. Eur J Hum Genet 26: 1180-1187. doi:10.1038/s41431-018-0155-x

Mirmohammadsadegh A, Marini A, Nambiar S, Hassan M, Tannapfel A, Ruzicka T, Hengge UR. 2006. Epigenetic silencing of the PTEN gene in melanoma. Cancer Res 66: 6546-6552. doi:10.1158/0008-5472.CAN-06-0384 
Mutter GL, Lin MC, Fitzgerald JT, Kum JB, Baak JP, Lees JA Weng LP, Eng C. 2000. Altered PTEN expression as a diagnostic marker for the earliest endometrial precancers. J Natl Cancer Inst 92: 924-930. doi:10.1093/jnci/92.11 .924

Mutter GL, Ince TA, Baak JP, Kust GA, Zhou XP, Eng C. 2001. Molecular identification of latent precancers in histologically normal endometrium. Cancer Res 61: 43114314.

Myers MP, Pass I, Batty IH, Van der Kaay J, Stolarov JP, Hemmings BA, Wigler MH, Downes CP, Tonks NK. 1998. The lipid phosphatase activity of PTEN is critical for its tumor supressor function. Proc Natl Acad Sci 95: 13513-13518. doi:10.1073/pnas.95.23.13513

Nelen MR, Padberg GW, Peeters EA, Lin AY, van den Helm B, Frants RR, Coulon V, Goldstein AM, van Reen MM, Easton DF, et al. 1996. Localization of the gene for Cowden disease to chromosome 10q22-23. Nat Genet 13: 114-116. doi:10.1038/ng0596-114

Nelen MR, Kremer H, Konings IB, Schoute F, van Essen AJ, Koch R, Woods CG, Fryns JP, Hamel B, Hoefsloot LH, et al. 1999. Novel PTEN mutations in patients with Cowden disease: absence of clear genotype-phenotype correlations. Eur J Hum Genet 7: 267-273. doi:10.1038/sj.ejhg .5200289

Ngeow J, Mester J, Rybicki LA, Ni Y, Milas M, Eng C. 2011. Incidence and clinical characteristics of thyroid cancer in prospective series of individuals with Cowden and Cowden-like syndrome characterized by germline PTEN, SDH, or KLLN alterations. J Clin Endocrinol Metab 96: E2063-E2071. doi:10.1210/jc.2011-1616

Ngeow J, Stanuch K, Mester JL, Barnholtz-Sloan JS, Eng C. 2014. Second malignant neoplasms in patients with Cowden syndrome with underlying germline PTEN mutations. J Clin Oncol 32: 1818-1824. doi:10.1200/JCO .2013.53.6656

Ni Y, Zbuk KM, Sadler T, Patocs A, Lobo G, Edelman E, Platzer P, Orloff MS, Waite KA, Eng C. 2008. Germline mutations and variants in the succinate dehydrogenase genes in Cowden and Cowden-like syndromes. Am J Hum Genet 83: 261-268. doi:10.1016/j.ajhg.2008.07.011

Ni Y, He X, Chen J, Moline J, Mester J, Orloff MS, Ringel MD, Eng C. 2012. Germline SDHx variants modify breast and thyroid cancer risks in Cowden and Cowden-like syndrome via $\mathrm{FAD} / \mathrm{NAD}$-dependent destabilization of p53. Hum Mol Genet 21: 300-310. doi:10.1093/hmg/ ddr459

Nieuwenhuis MH, Kets CM, Murphy-Ryan M, Yntema HG, Evans DG, Colas C, Moller P, Hes FJ, Hodgson SV, Olderode-Berends MJ, et al. 2014. Cancer risk and genotypephenotype correlations in PTEN hamartoma tumor syndrome. Fam Cancer 13: 57-63. doi:10.1007/s10689-0139674-3

Okkenhaug K. 2013. Signaling by the phosphoinositide 3-kinase family in immune cells. Annu Rev Immunol 31: 675704. doi:10.1146/annurev-immunol-032712-095946

Papa A, Wan L, Bonora M, Salmena L, Song MS, Hobbs RM, Lunardi A, Webster K, Ng C, Newton RH, et al. 2014. Cancer-associated PTEN mutants act in a dominant-negative manner to suppress PTEN protein function. Cell 157: 595-610. doi:10.1016/j.cell.2014.03.027
Parsa AT, Waldron JS, Panner A, Crane CA, Parney IF, Barry JJ, Cachola KE, Murray JC, Tihan T, Jensen MC, et al. 2007. Loss of tumor suppressor PTEN function increases B7-H1 expression and immunoresistance in glioma. Nat Med 13: 84-88. doi:10.1038/nm1517

Peng W, Chen JQ, Liu C, Malu S, Creasy C, Tetzlaff MT, Xu C, McKenzie JA, Zhang C, Liang X, et al. 2016. Loss of PTEN promotes resistance to T cell-mediated immunotherapy. Cancer Discov 6: 202-216. doi:10.1158/21598290.CD-15-0283

Perez-Tenorio G, Alkhori L, Olsson B, Waltersson MA, Nordenskjold B, Rutqvist LE, Skoog L, Stal O. 2007. PIK3CA mutations and PTEN loss correlate with similar prognostic factors and are not mutually exclusive in breast cancer. Clin Cancer Res 13: 3577-3584. doi:10.1158/1078-0432 .CCR-06-1609

Perren A, Weng LP, Boag AH, Ziebold U, Thakore K, Dahia PL, Komminoth P, Lees JA, Mulligan LM, Mutter GL, et al. 1999. Immunohistochemical evidence of loss of PTEN expression in primary ductal adenocarcinomas of the breast. Am J Pathol 155: 1253-1260. doi:10.1016/S00029440(10)65227-3

Ranieri C, Di Tommaso S, Loconte DC, Grossi V, Sanese P, Bagnulo R, Susca FC, Forte G, Peserico A, De Luisi A, et al. 2018. In vitro efficacy of ARQ 092, an allosteric AKT inhibitor, on primary fibroblast cells derived from patients with PIK3CA-related overgrowth spectrum (PROS). Neurogenetics 19: 77-91. doi:10.1007/s10048018-0540-1

Risinger JI, Hayes AK, Berchuck A, Barrett JC. 1997. PTEN/ MMAC1 mutations in endometrial cancers. Cancer Res 57: 4736-4738.

Risinger JI, Hayes K, Maxwell GL, Carney ME, Dodge RK, Barrett JC, Berchuck A. 1998. PTEN mutation in endometrial cancers is associated with favorable clinical and pathologic characteristics. Clin Cancer Res 4: 3005-3010.

Ruvalcaba RH, Myhre S, Smith DW. 1980. Sotos syndrome with intestinal polyposis and pigmentary changes of the genitalia. Clin Genet 18: 413-416. doi:10.1111/j.13990004.1980.tb01785.x

Sano T, Lin H, Chen X, Langford LA, Koul D, Bondy ML, Hess KR, Myers JN, Hong YK, Yung WK, et al. 1999. Differential expression of MMAC/PTEN in glioblastoma multiforme: relationship to localization and prognosis. Cancer Res 59: 1820-1824.

Schmidt EE, Ichimura K, Goike HM, Moshref A, Liu L, Collins VP. 1999. Mutational profile of the PTEN gene in primary human astrocytic tumors and cultivated xenografts. J Neuropathol Exp Neurol 58: 1170-1183. doi:10 .1097/00005072-199911000-00007

Schneider G, Schmidt-Supprian M, Rad R, Saur D. 2017. Tissue-specific tumorigenesis: context matters. Nat Rev Cancer 17: 239-253. doi:10.1038/nrc.2017.5

* Shen WH. 2019. PTEN as a guardian of the genome: pathways and targets. Cold Spring Harb Perspect Med doi:10 $.1101 /$ cshperspect.a036194

Shen WH, Balajee AS, Wang J, Wu H, Eng C, Pandolfi PP, Yin Y. 2007. Essential role for nuclear PTEN in maintaining chromosomal integrity. Cell 128: 157-170. doi:10 .1016/j.cell.2006.11.042

Shen-Li H, Koujak S, Szablocs M, Parsons R. 2010. Reduction of Pten dose leads to neoplastic development in mul- 
tiple organs of Pten ${ }^{\text {shRNA }}$ mice. Cancer Biol Ther 10: 1194-1200. doi:10.4161/cbt.10.11.13814

Simpson L, Parsons R. 2001. PTEN: Life as a tumor suppressor. Exp Cell Res 264: 29-41. doi:10.1006/excr.2000.5130

Singh SK, Dorak MT. 2017. Cancer immunoprevention and public health. Front Public Health 5: 101. doi:10.3389/ fpubh.2017.00101

Singh B, Ittmann MM, Krolewski JJ. 1998. Sporadic breast cancers exhibit loss of heterozygosity on chromosome segment 10q23 close to the Cowden disease locus. Genes Chromosomes Cancer 21: 166-171. doi:10.1002/(SICI) 1098-2264(199802)21:2<166::AID-GCC13>3.0.CO;2-P

Smith JM, Kirk EP, Theodosopoulos G, Marshall GM, Walker J, Rogers M, Field M, Brereton JJ, Marsh DJ. 2002. Germline mutation of the tumour suppressor PTEN in Proteus syndrome. J Med Genet 39: 937-940. doi:10 $.1136 /$ jmg.39.12.937

Smith IN, Thacker S, Jaini R, Eng C. 2019. Dynamics and structural stability effects of germline PTEN mutations associated with cancer versus autism phenotypes. J Biomol Struct Dyn 37: 1766-1782.

Sos ML, Koker M, Weir BA, Heynck S, Rabinovsky R, Zander T, Seeger JM, Weiss J, Fischer F, Frommolt P, et al. 2009. PTEN loss contributes to erlotinib resistance in EGFR-mutant lung cancer by activation of Akt and EGFR. Cancer Res 69: 3256-3261. doi:10.1158/00085472.CAN-08-4055

Spinelli L, Black FM, Berg JN, Eickholt BJ, Leslie NR. 2015. Functionally distinct groups of inherited PTEN mutations in autism and tumour syndromes. $J$ Med Genet 52: 128-134. doi:10.1136/jmedgenet-2014-102803

Stambolic V, Suzuki A, de la Pompa JL, Brothers GM, Mirtsos C, Sasaki T, Ruland J, Penninger JM, Siderovski DP, Mak TW. 1998. Negative regulation of PKB/Akt-dependent cell survival by the tumor suppressor PTEN. Cell 95: 29-39. doi:10.1016/S0092-8674(00)81780-8

Stambolic V, Tsao MS, Macpherson D, Suzuki A, Chapman WB, Mak TW. 2000. High incidence of breast and endometrial neoplasia resembling human Cowden syndrome in pten $^{+/-}$mice. Cancer Res 60: 3605-3611.

Stanger BZ, Stiles B, Lauwers GY, Bardeesy N, Mendoza M, Wang Y, Greenwood A, Cheng KH, McLaughlin M, Brown D, et al. 2005. Pten constrains centroacinar cell expansion and malignant transformation in the pancreas. Cancer Cell 8: 185-195. doi:10.1016/j.ccr.2005.07.015

Steck PA, Pershouse MA, Jasser SA, Yung WK, Lin H, Ligon AH, Langford LA, Baumgard ML, Hattier T, Davis T, et al. 1997. Identification of a candidate tumour suppressor gene, MMAC1, at chromosome 10q23.3 that is mutated in multiple advanced cancers. Nat Genet 15: 356-362. doi:10.1038/ng0497-356

Sun Z, Huang C, He J, Lamb KL, Kang X, Gu T, Shen WH, Yin Y. 2014. PTEN C-terminal deletion causes genomic instability and tumor development. Cell Rep 6: 844-854. doi:10.1016/j.celrep.2014.01.030

Tachibana M, Shibakita M, Ohno S, Kinugasa S, Yoshimura H, Ueda S, Fujii T, Rahman MA, Dhar DK, Nagasue N. 2002. Expression and prognostic significance of PTEN product protein in patients with esophageal squamous cell carcinoma. Cancer 94: 1955-1960. doi:10.1002/cncr .0678
Tan MH, Mester J, Peterson C, Yang Y, Chen JL, Rybicki LA, Milas K, Pederson H, Remzi B, Orloff MS, et al. 2011. A clinical scoring system for selection of patients for PTEN mutation testing is proposed on the basis of a prospective study of 3042 probands. Am J Hum Genet 88: 42-56. doi:10.1016/j.ajhg.2010.11.013

Tan MH, Mester JL, Ngeow J, Rybicki LA, Orloff MS, Eng C. 2012. Lifetime cancer risks in individuals with germline PTEN mutations. Clin Cancer Res 18: 400-407. doi:10 .1158/1078-0432.CCR-11-2283

Tashiro H, Blazes MS, Wu R, Cho KR, Bose S, Wang SI, Li J, Parsons R, Ellenson LH. 1997. Mutations in PTEN are frequent in endometrial carcinoma but rare in other common gynecological malignancies. Cancer Res 57: 39353940.

* Taylor H, Laurence ADJ, Uhlig HH. 2019. The role of PTEN in innate and adaptive immunity. Cold Spring Harb Perspect Med doi:10.1101/cshperspect.a036996

Teresi RE, Zbuk KM, Pezzolesi MG, Waite KA, Eng C. 2007. Cowden syndrome-affected patients with PTEN promoter mutations demonstrate abnormal protein translation. Am J Hum Genet 81: 756-767. doi:10.1086/521051

Tilot AK, Gaugler MK, Yu Q, Romigh T, Yu W, Miller RH, Frazier TW II, Eng C. 2014. Germline disruption of Pten localization causes enhanced sex-dependent social motivation and increased glial production. Hum Mol Genet 23: 3212-3227. doi:10.1093/hmg/ddu031

Tilot AK, Bebek G, Niazi F, Altemus JB, Romigh T, Frazier TW, Eng C. 2016. Neural transcriptome of constitutional Pten dysfunction in mice and its relevance to human idiopathic autism spectrum disorder. Mol Psychiatry 21: 118-125. doi:10.1038/mp.2015.17

Trotman LC, Pandolfi PP. 2003. PTEN and p53: who will get the upper hand? Cancer Cell 3: 97-99. doi:10.1016/S15356108(03)00022-9

Trotman LC, Niki M, Dotan ZA, Koutcher JA, Di Cristofano A, Xiao A, Khoo AS, Roy-Burman P, Greenberg NM, Van Dyke T, et al. 2003. Pten dose dictates cancer progression in the prostate. PLoS Biol 1: E59. doi:10.1371/journal.pbio .0000059

Trotman LC, Wang X, Alimonti A, Chen Z, Teruya-Feldstein J, Yang H, Pavletich NP, Carver BS, Cordon-Cardo C, Erdjument-Bromage H, et al. 2007. Ubiquitination regulates PTEN nuclear import and tumor suppression. Cell 128: 141-156. doi:10.1016/j.cell.2006.11.040

Venot Q, Blanc T, Rabia SH, Berteloot L, Ladraa S, Duong JP, Blanc E, Johnson SC, Hoguin C, Boccara O, et al. 2018. Targeted therapy in patients with PIK3CA-related overgrowth syndrome. Nature 558: 540-546. doi:10.1038/ s41586-018-0217-9

Vora SR, Juric D, Kim N, Mino-Kenudson M, Huynh T, Costa C, Lockerman EL, Pollack SF, Liu M, Li X, et al. 2014. CDK 4/6 inhibitors sensitize PIK3CA mutant breast cancer to PI3K inhibitors. Cancer Cell 26: 136149. doi:10.1016/j.ccr.2014.05.020

Waite KA, Eng C. 2002. Protean PTEN: form and function. Am J Hum Genet 70: 829-844. doi:10.1086/340026

Wang SI, Puc J, Li J, Bruce JN, Cairns P, Sidransky D, Parsons R. 1997. Somatic mutations of PTEN in glioblastoma multiforme. Cancer Res 57: 4183-4186.

Wang H, Douglas W, Lia M, Edelmann W, Kucherlapati R, Podsypanina K, Parsons R, Ellenson LH. 2002. DNA mis- 
J. Ngeow and C. Eng

match repair deficiency accelerates endometrial tumorigenesis in Pten heterozygous mice. Am J Pathol 160: 1481-1486. doi:10.1016/S0002-9440(10)62573-4

Wang S, Gao J, Lei Q, Rozengurt N, Pritchard C, Jiao J, Thomas GV, Li G, Roy-Burman P, Nelson PS, et al. 2003. Prostate-specific deletion of the murine Pten tumor suppressor gene leads to metastatic prostate cancer. Cancer Cell 4: 209-221. doi:10.1016/S1535-6108(03) 00215-0

Wang Y, Romigh T, He X, Tan MH, Orloff MS, Silverman RH, Heston WD, Eng C. 2011. Differential regulation of PTEN expression by androgen receptor in prostate and breast cancers. Oncogene 30: 4327-4338. doi:10.1038/onc .2011 .144

Wang Y, He X, Ngeow J, Eng C. 2012. GATA2 negatively regulates PTEN by preventing nuclear translocation of androgen receptor and by androgen-independent suppression of PTEN transcription in breast cancer. Hum Mol Genet 21: 569-576. doi:10.1093/hmg/ddr491

Wang Y, Yu Q, He X, Romigh T, Altemus J, Eng C. 2014 Activation of AR sensitizes breast carcinomas to NVPBEZ235's therapeutic effect mediated by PTEN and KLLN upregulation. Mol Cancer Ther 13: 517-527. doi:10.1158/1535-7163.MCT-13-0655

Wei Q, Clarke L, Scheidenhelm DK, Qian B, Tong A, Sabha N, Karim Z, Bock NA, Reti R, Swoboda R, et al. 2006. High-grade glioma formation results from postnatal Pten loss or mutant epidermal growth factor receptor expression in a transgenic mouse glioma model. Cancer Res 66: 7429-7437. doi:10.1158/0008-5472.CAN-06-0712

Weng LP, Smith WM, Dahia PL, Ziebold U, Gil E, Lees JA, Eng C. 1999. PTEN suppresses breast cancer cell growth by phosphatase activity-dependent $\mathrm{G}_{1}$ arrest followed by cell death. Cancer Res 59: 5808-5814.

Weng LP, Brown JL, Eng C. 2001a. PTEN coordinates $\mathrm{G}_{1}$ arrest by down-regulating cyclin $\mathrm{D} 1$ via its protein phosphatase activity and up-regulating p27 via its lipid phosphatase activity in a breast cancer model. Hum Mol Genet 10: 599-604. doi:10.1093/hmg/10.6.599

Weng LP, Smith WM, Brown JL, Eng C. 2001b. PTEN inhibits insulin-stimulated MEK/MAPK activation and cell growth by blocking IRS-1 phosphorylation and IRS-1/ Grb-2/Sos complex formation in a breast cancer model. Hum Mol Genet 10: 605-616. doi:10.1093/hmg/10.6.605

Whiteman DC, Zhou XP, Cummings MC, Pavey S, Hayward NK, Eng C. 2002. Nuclear PTEN expression and clinicopathologic features in a population-based series of primary cutaneous melanoma. Int J Cancer 99: 63-67. doi:10 $.1002 / \mathrm{ijc} .10294$

Wu X, Senechal K, Neshat MS, Whang YE, Sawyers CL. 1998. The PTEN/MMAC1 tumor suppressor phosphatase functions as a negative regulator of the phosphoinositide 3-kinase/Akt pathway. Proc Natl Acad Sci 95: 15587-15591. doi:10.1073/pnas.95.26.15587

Xiao A, Wu H, Pandolfi PP, Louis DN, Van Dyke T. 2002. Astrocyte inactivation of the $\mathrm{pRb}$ pathway predisposes mice to malignant astrocytoma development that is accelerated by PTEN mutation. Cancer Cell 1: 157-168. doi:10.1016/S1535-6108(02)00029-6

Xu X, Ehdaie B, Ohara N, Yoshino T, Deng CX. 2010. Synergistic action of Smad4 and Pten in suppressing pancre- atic ductal adenocarcinoma formation in mice. Oncogene 29: 674-686. doi:10.1038/onc.2009.375

Yanagi S, Kishimoto H, Kawahara K, Sasaki T, Sasaki M, Nishio M, Yajima N, Hamada K, Horie Y, Kubo H, et al. 2007. Pten controls lung morphogenesis, bronchioalveolar stem cells, and onset of lung adenocarcinomas in mice. J Clin Invest 117: 2929-2940. doi:10.1172/ JCI31854

* Yang Y, Yin Y. 2019. PTEN in chromatin remodeling. Cold Spring Harb Perspect Med doi:10.1101/cshperspect .a036160

Yeager N, Klein-Szanto A, Kimura S, Di Cristofano A. 2007. Pten loss in the mouse thyroid causes goiter and follicular adenomas: Insights into thyroid function and Cowden disease pathogenesis. Cancer Res 67: 959-966. doi:10 .1158/0008-5472.CAN-06-3524

Yehia L, Ngeow J, Eng C. 2019. PTEN-opathies: from biological insights to evidence-based precision medicine. $J$ Clin Invest 129: 452-464. doi:10.1172/JCI121277

You MJ, Castrillon DH, Bastian BC, O’Hagan RC, Bosenberg MW, Parsons R, Chin L, DePinho RA. 2002. Genetic analysis of Pten and Ink4a/Arf interactions in the suppression of tumorigenesis in mice. Proc Natl Acad Sci 99: 1455-1460. doi:10.1073/pnas.022632099

Yu W, He X, Ni Y, Ngeow J, Eng C. 2015. Cowden syndrome-associated germline SDHD variants alter PTEN nuclear translocation through SRC-induced PTEN oxidation. Hum Mol Genet 24: 142-153. doi:10.1093/hmg/ ddu 425

Yu W, Ni Y, Saji M, Ringel MD, Jaini R, Eng C. 2017. Cowden syndrome-associated germline succinate dehydrogenase complex subunit D (SDHD) variants cause PTEN-mediated down-regulation of autophagy in thyroid cancer cells. Hum Mol Genet 26: 1365-1375. doi:10.1093/hmg/ ddx037

Zak M, Ledbetter M, Maertens P. 2017. Infantile Lhermitte-Duclos disease treated successfully with rapamycin. J Child Neurol 32: 322-326. doi:10.1177/0883073 816681340

Zhang JG, Wang JJ, Zhao F, Liu Q, Jiang K, Yang GH. 2010. MicroRNA-21 (miR-21) represses tumor suppressor PTEN and promotes growth and invasion in non-smallcell lung cancer (NSCLC). Clin Chim Acta 411: 846-852. doi:10.1016/j.cca.2010.02.074

Zhao J, Chen AX, Gartrell RD, Silverman AM, Aparicio L, Chu T, Bordbar D, Shan D, Samanamud J, Mahajan A, et al. 2019. Immune and genomic correlates of response to anti-PD-1 immunotherapy in glioblastoma. Nat Med 25: 462-469. doi:10.1038/s41591-019-0349-y

Zhou XP, Gimm O, Hampel H, Niemann T, Walker MJ, Eng C. 2000. Epigenetic PTEN silencing in malignant melanomas without PTEN mutation. Am J Pathol 157: 1123 1128. doi:10.1016/S0002-9440(10)64627-5

Zhou X, Hampel H, Thiele H, Gorlin RJ, Hennekam RC, Parisi M, Winter RM, Eng C. 2001. Association of germline mutation in the PTEN tumour suppressor gene and Proteus and Proteus-like syndromes. Lancet 358: 210211. doi:10.1016/S0140-6736(01)05412-5

Zhou XP, Loukola A, Salovaara R, Nystrom-Lahti M, Peltomäki P, de la Chapelle A, Aaltonen LA, Eng C. 2002 PTEN mutational spectra, expression levels, and subcellular localization in microsatellite stable and unstable co- 
PTEN in Hereditary and Sporadic Cancer

lorectal cancers. Am J Pathol 161: 439-447. doi:10.1016/ S0002-9440(10)64200-9

Zhou XP, Marsh DJ, Morrison CD, Chaudhury AR, Maxwell M, Reifenberger G, Eng C. 2003a. Germline inactivation of PTEN and dysregulation of the phosphoinositol-3-kinase/Akt pathway cause human Lhermitte-Duclos disease in adults. Am J Hum Genet 73: 1191-1198. doi:10 $.1086 / 379382$
Zhou XP, Waite KA, Pilarski R, Hampel H, Fernandez MJ, Bos C, Dasouki M, Feldman GL, Greenberg LA, Ivanovich J, et al. 2003b. Germline PTEN promoter mutations and deletions in Cowden/Bannayan-RileyRuvalcaba syndrome result in aberrant PTEN protein and dysregulation of the phosphoinositol-3-kinase/Akt pathway. Am J Hum Genet 73: 404-411. doi:10.1086/ 377109 


\section{$\&_{\mathrm{CSH}}^{\infty} \&$ Cold Spring Harbor

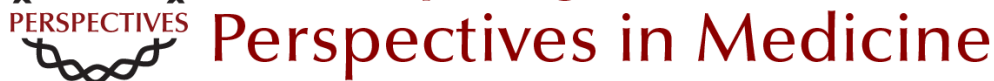

\section{PTEN in Hereditary and Sporadic Cancer}

Joanne Ngeow and Charis Eng

Cold Spring Harb Perspect Med 2020; doi: 10.1101/cshperspect.a036087 originally published online September 30, 2019

\section{Subject Collection The PTEN Family}

PTEN in Regulating Hematopoiesis and Leukemogenesis

Yilin Wu, Haichuan Zhu and Hong Wu

Connecting Genotype with Behavioral Phenotype

in Mouse Models of Autism Associated with

PTEN Mutations

Amy E. Clipperton-Allen and Damon T. Page

Metabolic Role of PTEN in Insulin Signaling and

Resistance

Yu Zhe Li, Antonio Di Cristofano and Minna Woo

Posttranslational Regulation and Conformational

Plasticity of PTEN

Larissa Kotelevets, Barbara Trifault, Eric Chastre, et al.

Toward Systems Pathology for PTEN Diagnostics Nahal Haddadi, Glena Travis, Najah T. Nassif, et al.

PTEN in Hereditary and Sporadic Cancer Joanne Ngeow and Charis Eng

PTEN Mouse Models of Cancer Initiation and Progression Yu-Ru Lee and Pier Paolo Pandolfi

Dual-Specific Protein and Lipid Phosphatase

PTEN and Its Biological Functions

Taojian Tu, Jingyu Chen, Lulu Chen, et al.
PTEN: Bridging Endocytosis and Signaling Matthew F. Lee and Lloyd C. Trotman

PTEN as a Guardian of the Genome: Pathways and Targets

Xinyi Fan, Jeffrey Kraynak, Jonathan P.S. Knisely, et al.

Discovery of the PTEN Tumor Suppressor and Its

Connection to the PI3K and AKT Oncogenes Ramon Parsons

The Complex Landscape of PTEN mRNA

Regulation

Erin Sellars, Martino Gabra and Leonardo Salmena

PTEN Nuclear Functions Jason Ho, Edward S. Cruise, Ryan J.O. Dowling, et al.

Structural Mechanisms of PTEN Regulation Glenn R. Masson and Roger L. Williams

PTEN in Chromatin Remodeling Jingyi Yang and Yuxin Yin

The Role of PTEN in Innate and Adaptive Immunity

Henry Taylor, Arian D. J. Laurence and Holm H. Uhlig

For additional articles in this collection, see http://perspectivesinmedicine.cshlp.org/cgi/collection/ 